\title{
Abstracts of Papers Presented at the Annual Meeting
}

\author{
SESSION 1A: BANKS AND THE PROBLEMS THEY CREATE
}

Why Didn't Canada Have a Banking Crisis in $2008 ?$

The growing number of careful empirical studies of the characteristics and regulation of financial institutions over the last two decades shed light on important facets of the recent financial crisis. However, we argue that the structural roots of the crisis are clearer when a longer perspective is taken. We use the comparative experience of Canada and the United States to demonstrate the strength of this approach. In the most recent crisis, in contrast to the U.S. experience, no Canadian banks failed or needed government support. But this is no isolated incident; it continues the experience of the two systems over the last 150 years. In this paper, we will document how the evolution and regulation of the banking systems and financial markets in the two countries encouraged differential degrees of risk taking.

\section{MiCHAEL BORDO, Rutgers University, ANGELA REDISH, University of British Columbia, and HUGH RocKOFF, Rutgers University}

\begin{abstract}
"Midas, Transmuting All, into Paper": The Bank of England and the Banque de France During the Napoleonic Wars
\end{abstract}

This paper reassesses Revolutionary and Napoleonic wartime economic policy in light of recent development in monetary theory and reemerging interest in balance sheets. We explain exactly how and why the Bank of England was able to adopt a set of flexible and accommodative policies and why the Banque de France was not. We interpret the actions of the central banks through stylized models on (i) optimal gold reserve holdings; (ii) asset liability management; and (iii) the public's inflation expectations formation. The key contribution of our analysis is that the government and the Bank of England combined economically, politically, and legally (with Acts of Parliament, Committees of investigation and influence on public opinion all employed) to ensure the ongoing solvency of the Bank of England, which allowed the Bank to continue to make substantial profits throughout the Napoleonic Wars, and as this was a credible arrangement, it allowed merchants to continue to trade with nonconvertible Bank of England notes and the government to finance the war effort with significant recourse to unfunded debt.

JAGJIT S. CHADHA, University of Kent, and Elisa NewBy, Fitzwilliam College, Cambridge

Credit Booms Gone Bust: Monetary Policy, Leverage Cycles, and Financial Crises, 1870-2008

The crisis of 2008/09 has focused attention on money and credit fluctuations, financial crises, and policy responses. In this paper, we study the behavior of money, credit, and macroeconomic indicators over the long run based on a newly constructed historical data set for 14 developed countries over the years 1870-2008, utilizing the 
data to study rare events associated with financial crisis episodes. We present new evidence that leverage in the financial sector has increased strongly in the second half of the twentieth century as shown by a decoupling of money and credit aggregates, and we also find a decline in safe assets on banks' balance sheets. We show for the first time how monetary policy responses to financial crises have been more aggressive post-1945, but how despite these policies the output costs of crises have remained large. Importantly, we demonstrate that credit growth is a powerful predictor of financial crises, suggesting that such crises are "credit booms gone wrong" and that policymakers ignore credit at their peril. It is only with the long-run comparative data assembled for this paper that these patterns can be seen clearly.

MORITZ SCHULARICK, Free University, Berlin, and Alan M. TAYLOR, University of California, Davis

\section{SESSION 1B: ECONOMIC GROWTH IN THE VERY LONG RUN}

\section{British Economic Growth, 1270-1870}

We provide annual estimates of GDP for England between 1270 and 1700 and for Great Britain between 1700 and 1870, constructed from the output side. The GDP data are combined with population estimates to calculate GDP per capita. We find English per capita income growth of 0.20 percent per annum between 1270 and 1700, although growth was episodic, with the strongest growth during the Black Death crisis of the fourteenth century and in the second half of the seventeenth century. For the period 1700-1870, we find British per capita income growth of 0.48 percent, broadly in line with the widely accepted Crafts/Harley estimates. This modest trend growth in per capita income since 1270 suggests that, working back from the present, living standards in the late medieval period were well above "bare bones subsistence." This can be reconciled with modest levels of kilocalorie consumption per head because of the very large share of pastoral production in agriculture.

\section{STEPHEN BROADBERRY, University of Warwick, BRUCE CAMPBELL, Queen's University, Belfast, ALEXANDER KLEIN, University of Warwick, MARK OVERTON, University of Exeter, and BAS VAN LEEUWEN, University of Warwick}

\section{When, Where, and Why? Early Industrialization in the Poor Periphery, 1870-1940}

This paper documents industrial output and labor productivity growth around the poor periphery 1870-1940 (Latin America, the European periphery, the Middle East, South Asia, Southeast Asia, and East Asia). Intensive and extensive industrial growth accelerated over these seven critical decades. There was an acceleration in the precocious leaders and more poor countries joined their club. Furthermore, many were actually catching up on Germany, the United States, and the United Kingdom. The paper then reports an early effort to identify the sources underlying the spread of the Industrial Revolution to the poor periphery. Productivity growth certainly made their industries more competitive in home and foreign markets, but other forces may have mattered more. Ever-cheaper labor gave them an edge in labor-intensive industries, increasingly cheap fuel and nonfuel intermediates from globally integrating markets appear to have taken resource advantages away from the European and North 
American leaders, and real exchange rate depreciation raised the price of importcompeting manufactured goods at home. Tariffs also helped protect the home market. All of this took place long before the post-World War II ISI strategies, especially in Latin America and Russia, where they had their origin.

JEFFREY G. WILLIAMSON, Harvard University and University of Wisconsin, Madison

How Unequal is Latin Inequality? Five Centuries of Inequality, Portugal, 1500-1910

This paper provides additional evidence on Latin inequality in the last five centuries by looking at new data on Portugal. We survey the evolution of wage income and income inequality in Portugal from the mid-sixteenth century to the early twentieth century. By utilizing new income and wealth data from an important historical university city, Coimbra, we are able to calculate a plethora of inequality measures across this large period, and we are able to investigate the interactions between income inequality and Portuguese economic development in the very long run. We find that: a) inequality started rising in the seventeenth century and reached a peak in the late eighteenth century, b) inequality is mostly between classes, supporting existing evidence on this issue in other countries, and c) wage premiums rose in the nineteenth century. We also conclude that inequality tended to rise in periods of low economic activity, but decreased in more dynamic periods.

Alvaro S. PereIra, Simon Fraser University, JAIME REIS, University of Lisbon, and ANA MARgarida Silva, Instituto de Ciêcias Sociais

\section{SESSION 2A: BANKS THAT AREN'T BANKS}

The Economics of Debt-Clearing Mechanisms in Europe from the Thirteenth to the Eighteenth Century

We examine the evolution of decentralized clearinghouse mechanisms from the thirteenth to the eighteenth century; in particular, we explore the clearing of nonor limited-tradable debts like bills of exchange. We construct a theoretical model of these clearinghouse mechanisms, similar to the models in the theoretical matching literature, and show that specific decentralized multilateral clearing algorithms known as rescontre, skontrieren, or virement des parties used by merchants were efficient in specific historical contexts. We can explain both the evolutionary self-organizing emergence of late medieval and early modern fairs, and its robustness during the seventeenth and eighteenth century.

LARS BOERNER, Free University of Berlin, and John WILliam HaTFIELD, Stanford University

God and Risk: The Role of Religiosity in Rural Banking in Early-Twentieth-Century Netherlands

What is the relationship between religiosity and risk in banking? The Netherlands' new cooperative movement at the turn of the twentieth century was instigated by religious groups - Roman Catholics, orthodox Calvinists, and liberal Protestants. This 
paper compares Dutch religious microfinance in two rural areas that differed by agricultural specialization, but were similar in having multiple Christian denominations represented. Using cliometric analysis combined with evidence from underused business archives, this paper investigates how religion mattered for the banks' credit, liquidity, interest rate, and market risks in the buildup to, during, and immediately following the price deflation of the 1920s. It finds various denominational differences in the level of risk, principally resulting from bankers' willingness and ability to diversify their portfolios of assets and liabilities. It concludes, however, that it was individual banks' religious minority or majority positions within their local markets that most affected their business behavior, regardless of actual denomination.

Christopher L. Colvin, London School of Economics

\section{Credit Intermediation in Eighteenth-Century Prussia: The Case of Landschaften}

The following paper studies the emergence of credit cooperatives, called "Landschaften" in eighteenth-century Prussia. Landschaften facilitated the refinancing of loans for Prussian estates by issuing covered bonds (Pfandbriefe) that were jointly backed by their members. They relied on a cooperative structure, joint liability, and local administration to overcome the problems of asymmetric information and moral hazard related to lending. This paper studies the design and operation of the Landschaften in detail and, based on microeconomic data for several different Landschaften, analyzes their effects on access and cost of credit for Prussian estates.

KIRSTEN WANDSChNEIDER, Occidental College

\section{SESSION 2B: TECHNOLOGY}

\section{Catching Up and Falling Behind: Knowledge Spillover from American to German Machine Toolmakers}

Contemporary German machine toolmakers accuse their Chinese competitors of violating patent rights and imitating German technology. A century ago, however, these German firms used the same methods to imitate American technology. To understand the dynamics of this catching-up process, we use patent statistics to analyze firms' activities between 1877 and 1932. We show that the German administration supported firms' imitation strategy by delaying the granting of patents to foreign applicants. Parallel to the growing international competitiveness of German firms, however, the willingness to guarantee intellectual property rights of foreigners was also increasing.

RALF RICHTER, Hans Böckler Foundation, and JOCHEN STREB, University of Hohenheim

Eras of Technological Convergence: Machine Tools and Mechanization in the United States, 1820-1929

Following up on the seminal insights of Nathan Rosenberg, this paper explores how, and how widely, technology converged among U.S. machine-tool using industries from 1820 through 1930. Convergence involved the invention and spread of 
machine tools, and both occurred in a variety of ways. Through the study of Brown and Sharpe company records, census data, and patenting by metalworking lathe inventors and machine tool firms, I argue that machine tools evolved through three stages of progressively wider convergence and different organizational forms. Through 1865 firms often made their own machine tools and used inventions in their own firms. Convergence was narrow, occurring through diversification by machinery firms, incipient sale of general purpose machine tools, and some worker mobility. From 1865 through the 1890 s machine tool firms became more central to the invention and dissemination of machine tools among industries. Widening mobility and new firm formation by workers trained by machine tool firms, along with some diversification, added to the convergence. After 1900 machine tool firms and their workers remained central to invention and diffusion for established industries and autos and other new sectors. But major innovations also emerged and spread from new sources making complements to machine tools, notably the steel and electrical industries, so that materials science and electrification had come to contribute to metalworking industries.

Ross THOMSON, University of Vermont

Technology-Skill Complementarity on the Eve of the Industrial Revolution: New Evidence from England (1710-1770)

This paper revisits the debate over whether the technological changes in eighteenthcentury England were skill substituting. As opposed to the existing literature that concentrates on the aggregate level, we exploit an exceptional and comprehensive set of evidence from tax records on apprentice indentures from all over Great Britain between 1710 and 1770 and look into the micro-mechanism of technologyskill complementarity. We base our analysis on the theoretical model presented in Goldin and Katz (1998), which focuses on the skill- and region-specific effect of the technological changes that took place in the mid-eighteenth century. Our results show that there was a continuous increase in the share of those being apprenticed to the manufacturing sector in general, and from the 1760s an increase in the share of those apprenticed to the mechanical trades. At the same time, a large and significant increase occurred in the second half of the 1730s in the relative premium paid in the mechanical trades relative to those other trades that were not affected by the technological changes. This increase in the relative premium is shown to be significantly affected by technological changes and not driven by changes in the number of apprentices.

KARINE VAN DER BEeK, Ben-Gurion University

SESSION 2C: THE ORIGINS AND CONSEQUENCES OF INSTITUTIONS

\section{Indigenous Origins of Colonial Institutions}

Variation in colonial institutions appears to explain differences in later political and economic development across former colonies. However, the origins of colonial institutions and the mechanisms through which institutions persist into the future are not well understood. This paper argues that precolonial, indigenous institutions influenced the different settlement and extractive strategies that guided colonial institutional development. We first test the argument by statistically analyzing an 
original data set of labor and tribute institutions from the precolonial and colonial periods for the 444 subnational territories in the Americas. The results indicate that precolonial institutions explain more of the variation in colonial institutions than existing explanations, such as indigenous population or national origin of colonists. Second, the paper illuminates the theory by tracing the mechanism of institutional persistence across five Mexican regions where indigenous institutions were vastly different. The paper suggests that variation in political and economic development today predates European colonialism.

LUZ Marina ARIas, University of California, San Diego, and Desha M. GIROD, Georgetown University

\section{Education Performance: Was It All Determined 100 Years Ago?}

This paper deals with institutional persistence in long-term economic development. We investigate the historical record of education in one of the fastest growing and most unequal societies in the twentieth century - the state of São Paulo, Brazil. Based on rich historical data on landholding and education, we assess the role played by factors such as quality of soil, land concentration, immigration, and the type of economic activity in determining supply and demand of education in the state of São Paulo during its emergence as Brazil's economic powerhouse, and to what degree these factors help explain current educational performance.

IRINEU DE CARVALHO FILHO, International Monetary Fund, and Renato P. Colistete, University of São Paulo

The Crisis of the Fourteenth Century Reassessed: Between Ecology and Institutions, Evidence from England (1310-1350)

On the basis of a vast corpus of archival evidence from late medieval England, the proposed paper aims to reassess the role of the environment and institutions in creating and intensifying the food crisis of the first half of the fourteenth century (c.1310-1350). It challenges the conventional wisdom that the crisis was confined to the years of bad harvests (1314/15-1322), and proposes to extend it until at least c.1337. It also challenges the idea that the crisis was created exclusively by bioecological factors. While there is no doubt that ecology was the first and foremost bringers of the crisis, one should also consider the contemporary institutions, as intensifiers of the crisis. The two factors, in fact, went hand-in-hand with each other and, as some sort of a double-headed hydra, brought much hardship on human populations.

PhILIP SLAVIN, McGill University

\section{SESSION 3A: INFORMATION: THE GOOD, THE BAD, AND THE MADE-UP}

\section{Defamation, Racketeering, and the French Financial Press Before World War I}

Reputation, a source of rents, cannot be conveniently insured and may lead agents to give up revenue to prevent circulation of false and damaging information. As a result, badmouthing is an instrument of racket and the press is likely to be used as a tool of extortion. This paper applies this argument in the context of the market for 
financial information in pre-World War I France. Using evidence on the industrial organization of the press and on badmouthing rackets, we provide two main results. First, we show that it did happen in specific segments of the news market and in specific situations. This is owing to the emergence of organizational solutions to deal with rumors. Second, to counteract the threat of badmouthing, flows of income are directed towards good journals. This conclusion may contribute to solve the puzzle of why rating managed to charge borrowers for their services.

VINCENT BIGNON, Graduate Institute, Geneva, and MARC FLANDREAU, Graduate Institute, Geneva

\section{Information Technology and Economic Change: The Impact of the Printing Press}

The printing press was the great innovation in early modern information technology, but economists have found no evidence of its impact in measures of aggregate productivity or income per person. This paper exploits new, city-level data on the establishment of printing presses in fifteenth-century Europe. I find that between 1500 and 1600 , cities where printing presses were established in the late 1400 s grew at least 60 percent faster than similar cities which were not early adopters. I employ difference-in-difference estimators and instrumental variable regressions to show that cities that adopted printing in the late 1400s had no prior growth advantage and that the association between adoption and subsequent growth was not due to printers choosing auspicious locations. These findings imply that the diffusion of printing accounted for between 20 and 60 percent of city growth 1500-1600. Historical evidence shows the printing press fostered the localized accumulation of practical knowledge.

JEREMIAH DitTMAR, American University

The Boats That Did Not Sail: Evidence on the Sources of Asset Price Volatility from an Eighteenth-Century Natural Experiment

How much of the short-run volatility of asset prices is due to the arrival of news and how much can be accounted for by the trading process? I use a natural experiment provided by financial history to address the question. During the eighteenth century, a number of British stocks were traded on the Amsterdam exchange and all relevant price information from England reached Amsterdam through the use of mail packet boats. I can precisely identify the arrival of boats and I use this to measure the influence of news on the volatility of the British stocks traded in Amsterdam. Results show that the volatility of stock prices was significantly higher after the arrival of news. Still, price movements in the absence of news were considerable. They amounted to between half and two-thirds of total volatility. This suggests an important role for factors not related to news in the day-to-day movement of asset prices.

Peter Koudiss, Universitat Pompeu Fabra 


\section{SESSION 3B: THE ECONOMIC HISTORY OF POLICY INTERVENTIONS IN THE UNITED STATES}

\section{The Impact of Rosenwald Schools on Black Student Achievement}

The black-white gap in completed schooling among Southern-born men narrowed sharply between the world wars after being stagnant for cohorts born between 1880 and 1910. We examine a large-scale school construction project, the Rosenwald Rural Schools Initiative, which was designed to improve the educational opportunities for Southern rural blacks. From 1914 to 1931 nearly 5,000 school buildings were constructed, serving approximately 36 percent of the black rural school-aged Southern population by 1930 . We use historical census data and World War II enlistment records to analyze the effects of the program on school attendance, literacy, high school completion, years of schooling, earnings, hourly wages, and migration. We find that the Rosenwald program accounts for at least 30 percent of the sizable educational gains of Southern blacks born during the 1910s and 1920s. In the longer run, exposure to the schools raised the wages of blacks who remained in the South relative to whites in the South by about 35 percent, implying a private rate of return to a year of additional schooling of about 17 percent. Moreover, Rosenwald significantly increased northbound migration of young adult blacks, likely fueling further income gains.

DANIEL AARONSON, Federal Reserve Bank of Chicago, and BhashKar MAZuMder, Federal Reserve Bank of Chicago

\section{Did the War on Poverty Cause Race Riots?}

This paper examines the causal relationship between War on Poverty outlays directed towards Community Action Agencies (CAAs) and the occurrence and severity of the race-related riots in the $1960 \mathrm{~s}$. Whereas many scholars and politicians have argued that CAAs were a prime example of well-intentioned, but ineffectual government intervention, this chapter demonstrates that CAAs were successful in discouraging the race riots and, therefore, a welfare-improving federal intervention. I employ an instrumental variables strategy, in a cross-sectional analysis, to determine the causal impact of CAA spending on riot occurrence and severity in which I take advantage of the targeting of federal funds to close electoral races. I also perform a semiparametric monthly panel analysis of riot occurrence. Spending on CAAs is found to have decreased the number of riots by 10-25 percent. Additionally, I find that political empowerment programs such as community organizing were the most effective in preventing rioting.

RoB GILlEZEAU, University of Michigan

\section{The Educational Legacy of the Greatest Generation: Veteran Status and Children's Educational Attainment}

This paper examines the impact of a father's World War II military service on the educational attainment of his children. The mechanism linking the two has been identified in the literature establishing positive impacts of parents' education and homeownership on their children's educational outcomes. In turn, a World War II veteran's educational attainment and homeownership status were influenced both by 
the direct impacts of military service and, as shown in previous studies, by loan guaranty and educational benefits provided in the GI Bill. I use two data sources to tie these strands of literature together. First, I draw a sample of World War II eligible men from the 1960 IPUMS 1 percent sample and examine the impact that fathers' veteran status had on their children's grade level. Second, I estimate impacts on high school and college completion using a sample of individuals from the original cohorts of the National Longitudinal Survey.

GRAY KIMBRough, University of North Carolina, Greensboro

SESSION 3C: THE ECONOMIC IMPLICATIONS OF IDENTITY

Religion or Knowledge Diffusion: A Protestant Economic History of China, 1840-1920

We provide an account of how Protestantism promoted economic prosperity in China- a country Weber ruled out for the development of Protestantism and capitalism. Using prefectural-level data from 1840-1920, a period when China was forced to open up to the West and experienced an early phase of capitalist development, we exploit the outcome of the Boxer Uprising to identify the causal effect of the subsequent diffusion of Protestantism on economic outcome. The seeming relationship between Protestantism and greater economic prosperity disappears once we control for the two channels through which knowledge was transmitted to the Protestant prefectures. The first pertains to the introduction of a Western primary education, whereas the second concerns practices of Western medicine. In contrast, the religious endeavors, most notably the erection of Bible schools, had no distinctly identifiable effect on economic prosperity.

YING BAI, Hong Kong University of Science and Technology, and JAMES KAI-SING KUnG, Hong Kong University of Science and Technology

Fragmented Networks and Entrepreneurship in Late Imperial Russia

Emergent economies often suffer from insufficient public institutions to enforce contract commitments and property rights. Informal reputation-based arrangements offer an alternative but they require both wide-spanning and closely knit networks that permit exchange partners to learn about each other's past behavior and enable collective sanctioning. The dilemma for emergent economies is that they typically lack such simultaneous network reach and cohesion, and are fragmented into various interest groups instead. How, then, is entrepreneurship possible under the twin condition of weak institutional support for economic activity and fragmented networks? We examine how partnership networks and reputation channel the mobilization of basic capital for new enterprises, using quantitative historical information on 4,172 corporate elite partnerships during the industrialization of late imperial Russia. Our evidence suggests that reputation is locally effective in small and isolated network components of founders who share similar ethnic, kinship, and regional origins. In contrast, founders situated in the network core benefit less from reputation and more from wide-reaching ties, brokerage opportunities, and diversity, which are systematically related to more successful capital mobilization.

Henning Hillmann, Stanford University, and BRANDY L. Aven, Stanford University 
Self-Employment in Jewish Communities: A Comparative Examination Across Time and Places

The paper examines comparatively the scope and patterns of self-employment in various Jewish communities over the last century. The analysis identifies two distinct self-employment "profiles." One is represented by the declining trend of selfemployment in Mandatory Palestine and later in Israel, resembling the dynamics driven by the negative effect of economic development on self-employment as generally found in the empirical literature. The other is the Diaspora profile, where persistently high self-employment rates, albeit compositionally changing over time, have characterized the Jewish populations in the United States and in other Western countries. Shifting patterns from small family businesses to professional and managerial pursuits highlight the changing role of Jewish self-employment, from safety net to upward mobility. Finally, it is suggested that while rational response to market opportunities and constraints may have been an important part of the story, the role of specific grouprelated factors cannot be ruled out at least as partial explanations for the distinct selfemployment profile of the Diaspora Jewry.

JACOB METZER, The Hebrew University of Jerusalem

\section{SESSION 4A: THE LEGAL FRAMEWORK OF ECONOMIC LIFE}

\section{Bankruptcy and the Rights of Debtors in Eighteenth-Century England}

In 1706 the English Parliament passed a bankruptcy statute which profoundly changed the rules of the game between debtors and creditors. From the earliest statute under Henry VIII in 1546, on the issuance of a writ of bankruptcy, all bankrupts' assets were seized, sold, and the proceeds distributed among the creditors on an equal prorated basis. The only way in which a bankrupt could emerge from bankruptcy was by paying in full all of his or her debts. This changed in 1706 when Parliament introduced rights for bankrupts. For those bankrupts deemed to have conformed to the process, the act provided for an allowance and the possibility of a certificate of discharge from the state of bankruptcy. For those debtors who willfully tried to hide assets, the statute increased the penalties to include capital punishment. With this statute, creditors lost the property right to a potential steam of income. Using a game-theoretic framework, this paper explores the effect of the new statue on debtors' incentives to truthfully report assets and on the welfare of both debtors and creditors. Using new contemporary data on discharge, we document the extent of discharge in the ten years following this legal change.

ANN M. CARLOS, University of Colorado, Boulder, and JENNIFER LAMPING, University of Colorado, Boulder

\section{Predators or Watchdogs? Bankers on Corporate Boards in the Era of Finance Capitalism}

Using newly collected data on investment banks and NYSE-traded firms, this paper analyzes how bank-firm relationships affected corporate governance and firm outcomes in the early twentieth century. The paper provides a new view into this question by exploiting a regulatory intervention that attempted to curtail bankers' presence on boards of directors. Following the Pujo Committee investigation of the "money trust" in 1912, the Clayton Antitrust Act of 1914 included provisions intended to weaken the 
influence of bankers in nonfinancial corporations. In particular, the act restricted the ability of investment and commercial bankers to sit on boards of competing firms, or, in the case of railroads, to sit on boards at all. The paper exploits this exogenous source of variation in bankers' presence on boards to determine in a causal manner whether the influence of bankers was beneficial or harmful to shareholders.

CAROLA Frydman, Massachusetts Institute of Technology, and ERIC HILT, Wellesley College

How to Regulate a Financial Market? The Impact of the 1893-1898 Regulatory Reforms on the Paris Bourse

The debate on the virtues of fragmentation vs. consolidation of securities markets has recently been reopened by the Mifid directive of the European Union and its ongoing review. Empirical assessments of these two options are rare because few substantial changes occur at this "meta-regulatory" level. The history of the Paris exchanges provides an interesting empirical test, since two changes in opposite directions occurred in the late nineteenth century, when Paris was the second financial center in the world. In 1893 the competition between the two Parisian markets was sharpened by a law diminishing the advantages of the regulated exchange; in 1898 another law brought them back and provided tools for their enforcement which lacked before 1893 . We analyze the impact of these two changes on the competition between the exchanges in terms of securities listed, traded volumes, and spreads. We conclude competition among exchanges is a delicate matter and efficiency is not always where one would think.

PIERRE-Cyrille Hautcoeur, EHESS-PSE, AMIR REZAEE, Université d'Orléans-EDHEC, and ANGELo RIVA, EGS-IDHE Paris Ouest

\section{SESSION 4B: NATURAL RESOURCES}

The Political Economy of Land Privatization in Argentina and Australia, 1810-1856

We compare the policies of public land disposal in the first half of the nineteenth century in Argentina and Australia, two frontier societies with similar endowments of abundant land. We develop a dynamic model of disputed frontier land claims with two ethnically self-identified nations who simultaneously claim rights to land. The model provides insights on how changes in the terms of trade affect private demand for land claims and how the density of settlement at frontier affects the cost of enforcing land claims. Both governments initially adopted policies restricting settlement beyond an officially defined boundary and both eventually adopted policies accommodating private demands for frontier lands. We find that although the two countries followed similar paths with respect to land policies, the mechanisms by which the accommodations occurred differed substantially in the two countries, as settler demands were filtered through governments with different objectives, strengths, and political institutions. 


\section{Farming the Ogallala Aquifer: Short- and Long-Run Impacts of Groundwater Access}

In the United States Great Plains, the Ogallala aquifer provides particular counties with valuable groundwater. The 1950s invention of central pivot irrigation made this groundwater available for large-scale agricultural production. Irrigation became critical for Great Plains agriculture, but the aquifer has become depleted over time and some counties have lost access to groundwater. This research aims to quantify the historical impacts of access to the Ogallala aquifer, comparing counties and time periods with varying access to its groundwater. Research questions focus on the value of water in agricultural production; the magnitude and speed of agricultural adjustment to water availability; the magnitude of "common pool" inefficiencies; how incentive schemes might encourage optimal use; and how changes in the agricultural sector influence other economic sectors. The Great Plains are not alone in facing severe water shortages, and the Ogallala region's experience may help understand the importance of water and management of externalities.

RICHARD HORNBECK, Harvard University, and PINAR KESKIN, Harvard University

\section{The Impact of Commodity Price Volatility on Resource Intensive Economies}

Commodity price volatility is bad for macroeconomic performance. Virtually all empirical studies that document this negative relationship rely on the estimation of aggregate growth equations using cross-section evidence drawn from the post-1970 era. This paper uses a simulation model, designed to be consistent with predictions made by renewable resource, production, and finance theory, to determine why commodity price volatility affects investment decisions, production levels, profitability, and ultimately long-run growth. The Canadian forestry sector is used as a case study to assess the importance of each of these effects. Simulation exercises reveal the extent to which commodity price volatility shocks significantly reduce forestry firms' equity prices and their demand for reproducible and natural capital. As a result of these changes in the firms' external financing costs and investment incentives, extraction costs rise, output levels and profits fall, and real GDP per capita growth slows.

IAN KEAY, Queen's University, Ontario

\section{PLENARY SESSION: FAULT LINES: HOW HIDDEN FRACTURES STILL THREATEN THE WORLD ECONOMY}

As the world recovers from the recent crisis, many commentators have pointed the finger at greedy bankers and incompetent regulators. In Fault Lines, I argue that serious flaws in the economy are also to blame.

I show how the individual choices that collectively brought about the economic meltdown - made by bankers, government officials, and ordinary homeowners - were rational responses to a flawed global financial order in which the incentives to take on risk are out of step with the dangers those risks pose. I trace the deepening fault lines in a world overly dependent on the indebted American consumer to power global growth and stave off global downturns; a system where America's growing inequality and thin social safety net create tremendous political pressure to encourage easy credit and to keep job creation robust, no matter what the consequences to the economy's long-term 
health; and where the U.S. financial sector, with its skewed incentives, is the critical but unstable link between an overstimulated America and an underconsuming world.

I demonstrate how unequal access to education and healthcare in the United States is eroding the quality of its policymaking, even while the growth paths chosen by large countries like Germany, Japan, and now China place an undue burden on the United States to get its policies right. I outline the hard choices we need to make to ensure a more stable world economy and restore lasting prosperity.

Speaker, RAGHURAM RAJAN, University of Chicago Commentator, JEAn-LAURENT Rosenthal, California Institute of Technology

\section{SESSION 4C: WHEN PEOPLE MOVE}

\section{Settler Skills and Colonial Development}

Settler groups are not homogenous. Although the arrival of the French Huguenots in 1688 is heralded as the event that buttressed European settlement in the Cape Colony of South Africa, their impact was not limited to explaining the rapid growth of the population circa 1700 . Using tax records, we show that, controlling for various factors, the French were more adept at viticulture than the non-French farmers at the Cape. Standard factors of production or institutional factors usually associated with faster growth do not explain the differences between the two groups. We posit that the skills of French matter in explaining the productivity differences. We test this hypothesis by dividing the French settlers into two groups: those originating from wine regions, and those from wheat regions. We find that descendants of settlers from wine regions in France were more productive winemakers in their adopted homeland than their non-wine compatriots, whose production function resembled more closely those of the Dutch and German farmers. This important insight - that home-country production function determines settler society production functions even in later generations - sheds new light on our understanding of how newly settled colonial societies develop.

JOHAN FOURIE, Stellenbosch University, Utrecht University, and DIETER VON FINTEL, Stellenbosch University

\section{Immigration and the Diffusion of Technology: The Huguenot Diaspora in Prussia}

This paper analyzes the long-term effect of technological diffusion on productivity caused by immigration of skilled workers. In 1685 religious persecution drove highly skilled Huguenots into the backward Brandenburg-Prussia where they established themselves and transferred technological knowledge to natives. We find that textile manufactories installed in towns hosting the Huguenots achieved higher productivity than others due to diffusion, even 100 years after immigration. Identification is based on an instrumental variable approach exploiting variation in the settlement of Huguenots which results from population losses due to plagues during the Thirty Years' War, effectively eliminating worries of selectivity in the settlement pattern.

ERIK HORNUNG, University of Munich 


\section{Moveable Feasts: A New Approach to Endogenizing Tastes}

We provide a new empirical approach to endogenizing tastes in consumer demand. We argue that tastes can be understood as the result of utility maximizing behavior in the past, whose properties can be used to partially endogenize tastes. As the old maximization problem depends critically on relative prices, we use old relative prices to endogenize tastes, overcoming many of the empirical criticisms of the taste formation literature while at the same time being consistent with a broad class of existing theoretical approaches to taste and preference formation. To test the empirical implications of our approach, we estimate the demand for food using unique household consumption and price data from the nineteenth century. We use contemporaneous relative prices and old relative prices from the home countries of immigrants measured fifteen years prior to our consumption survey. We first establish that the old relative prices are uncorrelated with the contemporaneous relative prices. We then find that older relative prices have a large and significant effect on the demand for food. We also provide suggestive evidence of persistence - the effect of old relative prices on demand persists more than 40 years later.

Trevon D. Logan, Ohio State University, and PAUL W. RHODE, University of Michigan

\section{SESSION 5A: BANKING AND FINANCE: EUROPEAN PERSPECTIVES}

\section{Are Stocks Always Good in the Long Run? Evidence from Belgium, 1838-2008}

We investigate the long-run performance of Belgian stocks listed on the Brussels Stock Exchange in each of the 2,052 months of the period 1838-2008. Our sample covers all stocks in the market over the entire period. Long-term real stock returns are frequently negative, but in the very long run they are almost always higher than risk-free returns. Remarkably, Sharpe ratios are very volatile over time. Stock returns strongly depend on dividend yields: real capital appreciation tends to be negative. We find no consistent differences between small stocks and large stocks returns.

JAN ANNAERT, University of Antwerp, FRANS BUELENS, University of Antwerp, and MARC DELOOF, University of Antwerp

The Value of Regulation and Reputation: Going Public in London and Berlin, 1900-1913

The emergence of an active IPO market was essential to the process of industrial development. A well-functioning market required the trust of stock market investors as ownership separated from control. Previous research has questioned how effective were regulation and reputation in improving the functioning of the IPO market. In this paper, we undertake a comparative study of the IPO markets between 1900 and 1913 in regulated Berlin and laissez-faire London, where two-thirds of IPOs occurred by way of the popular and unregulated Special Settlement method. Preliminary results indicate that although all IPOs on the Berlin stock exchange survived, around one in five firms going public in London by way of Special Settlement failed. Hence, regulation and reputation had a beneficial impact on IPO survival. Whilst there were some long-term "winners" amongst the latter IPOs, investors saw these 
gains overwhelmed by their losses from failed IPOs. Here was early evidence that unregulated and uncertified IPO markets were bad for investor wealth.

CARSTEN BURHOP, University of Cologne, and DAVID CHAMBERS, University of Cambridge

\section{Contingent Capital and Disorderly Deleveraging: Evidence from British Banking Experience in Prewar Era}

The recent financial crisis highlights the reluctance — and inability — of banks to issue equity and recapitalize themselves during a period of uncertainty. The goal of this project is to examine the arrangement in Britain between banks and their shareholders during the late nineteenth and early twentieth century in which the latter were obligated to pay the unpaid portion of capital into banks upon the request from the board. We test whether such "contingent capital" helps banks avoid disorderly deleveraging in time of financial fragility, using the detailed bank-level data on the amount of contingent capital, deposit and loan growth, and the overall share price performance of banks.

RICHARD S. GROSSMAN, Wesleyan University, and MASAMI IMAI, Wesleyan University

\section{SESSION 5B: RAISING AND SPENDING THE PUBLIC'S MONEY}

Big BRICs, Weak Foundations: The Beginning of Public Elementary Education in Brazil, Russia, India, and China, 1880-1920

Our paper studies the relationship between fiscal decentralization and the provision of elementary education in four of the largest economies at the turn of the last century: Brazil, Russia, India, and China (BRIC). Most comparative research in economic history has focused on either differences within developed economies or differences between developed and developing economies. We depart from this comparative tradition and focus exclusively on BRIC. Unlike other big economies at this time such as the United States and Germany, the BRICs had very low levels of educational attainment both in terms of enrollment and literacy. Using new comparative data from published and archival sources, we construct national and subnational series on educational inputs and outputs and detailed accounts of the fiscal structures of each country to assess whether and how fiscal decentralization influenced educational outcomes within BRICs.

LATIKA CHAUDARY, Scripps College, Aldo MusaCCHIO, Harvard Business School, STEVEn NAFZIGER, Williams College, and SE YAN, Peking University

\section{Warfare and Taxation in Preindustrial Europe: Evidence from the Italian Risorgimento}

This paper examines the interplay between warfare and taxation in nineteenthcentury Italy, from the end of the Napoleonic era in 1815 to unification in 1861. The institutional variety at the regional level makes the Italian peninsula a unique testing ground for comparative study. Using a new database, we argue that pre-unitary states pursued different fiscal policies in response to diverse domestic and external political 
environments. Our long-run empirical analysis complements recent theoretical works about state capacity. By emphasizing public finances, we also uncover novel insights into the process of state formation in Italy.

MARK DINCECCO, IMT Lucca Institute for Advanced Studies, GIOVANNI FEDERICO, European University Institute and University of Pisa, and ANDREA VIndigni, Princeton University

One System, Seventeen Outcomes? Exploring Public Finance Policies and Outcomes in the Low Countries, 1514-1795

To better understand the relationship between economic growth and the modernization of public finance in early modern Europe, this paper explores the history of public debt management in the Low Countries between the sixteenth and eighteenth century. The public debt system created in the mid-sixteenth century under Habsburg rule produced spectacular results in one province, Holland, but never in the other sixteen provinces. To explain this remarkable divergence, the paper compares the political and fiscal organization, economic outlook, and debt issuing policies of the seventeen provinces. The comparison shows that Holland owed its success not to a major constitutional revolution but to continuous changes in fiscal and financial institutions, including the bond market, and to a precocious economic development with the attendant surge in tax revenues and accumulated wealth.

OSCAR GELDERBLOM, University of Utrecht, and JOOST JONKER, University of Utrecht

\section{SESSION 6A: HEALTH AND HUMAN CAPITAL}

Was What Ail'd Ya' What Kill'd Ya'?

Making use of those Union Army veterans for whom death certificates are available, we compare the conditions with which they were diagnosed by Civil War pension surgeons to the cause(s) of death on the certificates. We divide the data into those veterans who entered the pension early because of war injuries to those who entered the pension after the 1890 reform that made it available to many more veterans. We examine the correlation between the accumulation of conditions to time until death to gauge support for the "insult hypothesis." We also examine the correlation between specific conditions and death causes to gauge support for the hypothesis that death is more likely attributable to a specific cause. In general, we find some support forboth hypotheses. We find few differences between those who entered the pension before and after 1890 .

Brian BETTENHAUSEN, University of Chicago,
JOSEPH BURTON, University of Chicago,
LOUIS CAIN, University of Chicago, and
ROBERT Fogel, University of Chicago

Do Electoral Systems Affect Your Health? Evidence from the Epidemiological Transition

Between 1870 and 1930 life expectancy improved dramatically. For example, life expectancy at birth rose from 41 years to almost 60 years in Switzerland with similar 
developments in neighboring European countries. While several studies analyze the role of nutrition, education or public infrastructure, none has considered the political economy of these dramatic health improvements. This article uses new archival sources from Switzerland since 1881 to study the role of political institutions and in particular the electoral system. Since politicians elected under proportional representation have stronger incentives to invest in broad goods (such as public education), the adoption of proportional representation might have contributed to the mortality decline. Based on detailed mortality statistics by cause, age, gender for each canton from 1881 to 2000 , we find that infant mortality rates decline by 2 or $4-5$ percent and the crude death rate by 0.15 or about 2 percent after the switch to proportional representation.

CHRISTINA GATHMANN, University of Mannheim, and STEFFEN REINHOLD, University of Mannheim

\section{Skilled Labor Mobility During the Second Industrial Revolution}

This paper explores the role of human capital on earnings and other measures of job performance during the late nineteenth century. During this time, U.S. Naval officers belonged either to a regular or an engineer corps and had tasks assigned for their specialized training and experience. To test for the effects of specialized skills on performance, we compile educational data from original-source Naval Academy records for the graduating classes of 1858 to 1905 . We merge these with career data extracted from official Navy registers for the years 1859 to 1907. This compilation comprises one of the longest and earliest longitudinal records of labor market earnings, education, and experience of which we are aware. Our results suggest that greater technical skill translated into higher earnings early in careers, but that wage premia diminished as careers progressed. From this evidence, we argue that technical progress was more skill-depreciating than skill-biased during this period.

DARRELl J. GlaSER, United States Naval Academy, and AHMED S. RAHMAN, United States Naval Academy

\section{SESSION 6B: WHEN BONDS GO BAD}

\section{How Big is the Financial Penalty for Dictators? The Case of Cuban Bonds}

This paper examines whether a specific risk premium associated with "odious" sovereign debt issued by dictators exists. Bondholders could indeed require a premium to compensate for the higher default risk due to the odious character of the debts. The paper quantifies the risk premium required by investors to hold debts which could be denounced as odious and analyzes the relation between the value of the government bond and the extreme "odious debt" events. Based on an original database of Cuban bonds, the paper reveals the existence of a risk premium of at least 200 basis points which penalizes bonds issued by dictatorial regimes. The bond market "odious" shocks are provided by a Structural VAR analysis. As the Cuban bonds were quoted both in Brussels and in Madrid, a comparative research between the two exchanges confirms that the bond price evolution incorporates an "odious debt" premium. 
This article seeks to identify "turning points" by evaluating the impact of events affecting the Chinese internal bond market from 1921 to 1942 . We find that some external wars that are generally thought to be crucial are clearly mirrored in the bond market, such as the Japanese Invasion in Manchuria and the outbreak of the second Sino-Japanese War. We suspect that some events (e.g., the Sino-Japanese CeaseFire in Tanggu) have been downplayed by historians. Surprisingly, an event like the Japanese attack on Pearl Harbor which has been assigned a central place was found no financial effect. Interestingly, we show external conflicts had stronger long-term impacts than major civil conflicts had on the bond yields, while their short-term influences were similar. We conclude that the bond market reveals an "objective" version of the history of the Republic Era.

Chun-Yu Ho, Georgia Institute of Technology, and DAN LI, Fudan University

What is Worst, Trade Crisis or Revolution? Foreign Creditors, Sovereign Debt, and Bailouts in Brazil and Mexico, 1912-1914

This paper compares the sovereign loans granted to Brazil and Mexico during the crises that hit those countries between 1912 and 1914. The Brazilian and Mexican fiscal positions were deteriorated by falling coffee prices and the Revolution, respectively. Brazil was able to borrow at 1.67 percent risk premium, whilst Mexico was granted with much more expensive credit, at 3.13 percent risk premium. This paper assesses why creditors granted these peculiar loans at such discrepant terms. It asserts that both operations were launched because creditors were exposed to those countries. However, Rothschilds - the main Brazilian lender-believed that payment capacity would recover once coffee prices increased, and therefore expected that the bonds it underwrote would end up being profitable. In contrast, Mexican creditors realized that the Revolution would last for years, and therefore could not provide that politically fragile government with the cheap credit it needed to service the sovereign debt.

LEONARDO WeLLER, London School of Economics 